\title{
Effects Of Voluntary Disclosure Of The Schedule Of Manufacturing Cost On Analysts' Earnings Forecasts: Evidence From Korea
}

Hyunmin Oh, Hanyang University, South Korea

Sambock Park, Hanyang University, South Korea

Heungjoo Jeon, Dankook University, South Korea

\begin{abstract}
We provide the effects of voluntary disclosure of the schedule of manufacturing cost on analysts'earnings forecasts. We set up and analyze the disclosure of the schedule of manufacturing cost as a proxy for voluntary disclosure. Specifically, we examine the associations between voluntary disclosure of it and the accuracy of analysts' earnings forecasts and bias in earnings forecasts. The results of our study are as follows. First, the relationship between voluntary disclosure of the schedule of manufacturing cost and the accuracy of analysts' earnings forecasts is significant in the positive (+) direction. This means that the accuracy of analysts' earnings forecasts is higher in the case of the firms that voluntarily disclosed the schedule of manufacturing cost, as compared to other firms. Second, the relationship between voluntary disclosure of the schedule of manufacturing cost and analysts' bias in earnings forecasts is significant in the negative (-) direction. This means that analysts underestimate earnings in the case of the firms that voluntarily disclose the schedule of manufacturing cost, as compared to other firms. Since the schedule of manufacturing cost is still an interesting item and useful information in the capital market, the results of our study provide important implications not only to managers, but also to investors and supervisory authority. Limitations of our study include the fact that not all diverse variables that affect voluntary disclosure and analysts' forecasts are considered.
\end{abstract}

Keywords: Voluntary Disclosure; The Schedule of Manufacturing Cost; Analysts’ Forecasts

\section{INTRODUCTION}

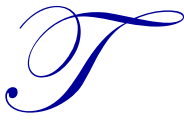

his study examines the effects of voluntary disclosure of the schedule of manufacturing cost on analysts' earnings forecasts. Specifically, a firm that disclose all five items (raw materials, labor costs, manufacturing overheads, total manufacturing cost for the year, manufacturing cost during the year) among items of the schedule of manufacturing cost is defined as a firm (VDUM) that voluntarily disclosed it. Next, we examine the associations between voluntary disclosure of it and the accuracy of analysts' earnings forecasts and bias in earnings forecasts.

Voluntary disclosure is a system that enables public firms to disclose major management information regarding the relevant firms, with the exception of important management matters, through a voluntary judgment by the relevant firms by expanding the items for voluntary disclosure that have been limited to only some items with a view to enhancing the disclosure ability of public firms ${ }^{1}$. Voluntary disclosure is one of various forms of non-scheduled disclosure among the types of disclosure in the circulation market and plays the role of providing firm information when the securities supplied to the market are traded among investors.

Firms will voluntarily disclose information on them to solve the problem of information asymmetry between capital providers and managers and the agency problem resulting from the separation of ownership and control. By contrast,

${ }^{1}$ Korea Exchange (http://www.krx.co.kr/)

Copyright by author(s); $\underline{\mathrm{CC}-\mathrm{BY}}$ 
managers may have incentives to provide information arbitrarily, because voluntary disclosure is neither compulsory, nor verified by a third party. In such situations, voluntary disclosure may rather aggravate information asymmetry, because managers may have incentives to hide unfavorable information and selectively provide only favorable information (Sohn et al., 2008; Oh and Shin, 2016).

Previous studies regarding voluntary disclosure have focused on information asymmetry reduction and its effects on the capital market (Diamond and Verrecchia, 1991; Verrecchia, 1999). The results of previous studies demonstrate that voluntary disclosure generally contributes to reductions in information asymmetry, leading to positive responses in the capital market. However, not all effects of voluntary disclosure are positive. Some studies indicate positive functions of voluntary disclosure, such as reductions in capital costs (Lee and Shin, 2010; Na and Leem, 2014), while other results report that voluntary disclosure rather increases information asymmetry, as errors in analysts' earnings forecasts are larger in firms that actively implement voluntary disclosure (Sohn et al., 2008; Oh and Shin, 2016).

One of major causes of the controversies in the results of previous studies is difficulties in the quantification of disclosure information, which is qualitative, into objective measures. That is, the validity of study results regarding disclosure relies on the objectivity of the measures of disclosure quality. Accordingly, domestic disclosure- related studies used diverse proxies to measure disclosure quality. Such proxies include management forecasts, autonomous disclosure information, and the evaluation scores regarding disclosure of the Korea Corporate Governance Service used for fair disclosure. In this study, we use whether or not to disclose of the schedule of manufacturing cost as a proxy of disclosure quality ${ }^{2}$. Due to the amendment of financial reporting standard no. 21 , the schedule of manufacturing cost have been changed from an item for mandatory disclosure to an item for voluntary disclosure. The change in the disclosure environment from mandatory disclosure that must observe the disclosure regulations of regulatory authorities to voluntary disclosure will have large effects on the information environment in the capital market. To examine the information usefulness of voluntary disclosure, we analyze the effects of voluntary disclosure of the schedule of manufacturing cost on analysts' earnings forecasts for the period from 2004 to 2014.

Analysts play the role of reducing information asymmetry between firms and investors by accurately analyzing information provided by firms and providing the processed information to the capital market. They have more expertise on accounting information and play the role of information brokers who produce and deliver information on firms' intrinsic values (Shipper, 1989). In other words, if they accurately figure out the quality of earnings and provide this information to the capital market, information risks can be removed (Oh, 2016). Our results provide useful implications for the capital market by showing how voluntary disclosure of the schedule of manufacturing cost interpret and transmit information by financial analysts.

Our results contribute to the literature in several ways. First, we use whether or not to disclose the schedule of manufacturing cost as a proxy of voluntary disclosure. The disclosure of the schedule of manufacturing cost, which has been changed from an item for mandatory disclosure to an item for voluntary disclosure by the amendment of the financial reporting standards, provides appropriate study environment for the analysis of the effects of voluntary disclosure on the capital market.

Second, the significance of our study lies in that it empirically analyzes the effects of the disclosure of the schedule of manufacturing cost on changes of information asymmetry in the capital market by examining the association between voluntary disclosure the schedule of manufacturing cost and analysts' earnings forecasts.

The remainder of the paper is organized as follows. Section 2 reviews the related literature and develops the testable hypotheses. Section 3 discusses the research design. Section 4 presents the empirical results of the study. Finally, section 5 concludes the study.

\footnotetext{
${ }^{2}$ On December 24, 2004, the Financial Services Commission announced that the amended financial reporting standard should be applied to business reports for 2004 and thereafter. The schedule of manufacturing cost had been an item for compulsory disclosure and was changed into an item for voluntary disclosure for business reports for 2004 and thereafter. Therefore, voluntary disclosure the schedule of manufacturing cost is meaningful as a proxy of voluntary disclosure.
} 


\section{LITERATURE REVIEW AND HYPOTHESES DEVELOPMENT}

Voluntary disclosure of financial information generates changes in the information asymmetry between firms and shareholders (Healy and Palepu, 2001). The possibility of involvement of firms' discretion in compulsory disclosure is low, because severe sanctions will be imposed by regulatory authorities against violations of the regulations related to compulsory disclosure. However, voluntary disclosure can be regarded as a manifestation of active will of firms to reduce information asymmetry between them and external users (Na and Leem, 2014) ${ }^{3}$. Therefore, previous studies regarding voluntary disclosure have focused on the determinants of voluntary disclosure, whether or not voluntary disclosure reduces information asymmetry, and the effects of the decrease of information asymmetry on the capital market. We examine the association between analysts who play an important role in reducing the information asymmetry in the capital market and voluntary disclosure.

Major motives of public firms' disclosure include the decrease in information asymmetry and capital cost saving (Diamond and Verrecchia, 1991; Verrecchia, 1999). Increases in the levels of disclosure lead to decrease in information asymmetry and capital costs (Botosan, 1997; Francis et al., 2008). Based on the nature of disclosure, Lee and Shin (2010) classified cases of disclosure into favorable disclosure cases and unfavorable disclosure cases and analyzed the effects of the nature of disclosure on capital costs. They found that voluntary disclosure reduce capital costs and firms are making efforts to reduce information asymmetry between them and information users by actively disclosing not only favorable, but also unfavorable information.

Heflinet et al. (2003) analyzed the effects of the introduction of the fair disclosure system on analysts' earnings forecasts. They reported that the accuracy and variance of analysts' earnings forecasts do not change after the introduction of the fair disclosure system. This indicates that the introduction of the fair disclosure system at least does not cause damage to information environment. In addition, Shane et al. (2001) reported that the accuracy of analysts' earnings forecasts is not reduced after the introduction of the fair disclosure system, although there is the uncertainty of information collection due to the prohibition of provision of selective information to users.

Meanwhile, some of the results of previous studies indicate that voluntary disclosure rather aggravates information asymmetry. Agrawal et al. (2006) reported that the accuracy of analysts' earnings forecasts decreases and the variance increases after the introduction of the fair disclosure system. Irani and Karamanou (2002) reported that the variance of analysts' earnings forecasts increase and the number of analysts decrease after the introduction of the fair disclosure system. The cause of this tendency relates to the fact that analysts have difficulties in collecting professional information due to the introduction of the fair disclosure system.

Sohn et al. (2008) examined the associations between voluntary disclosure and the variance of and errors in analysts' forecasts. According to the results of this analysis, when the level of voluntary disclosure is higher, the variance of analysts' earnings forecasts is smaller and errors in analysts' earnings forecasts are larger. These results are interpreted that when firm's discretion is involved in voluntary disclosure to a high degree, analysts' forecasts are biased in a certain direction, leading to the increase of information asymmetry between firms and investors.

In the amended financial reporting standard No.21, the disclosure of the details of composition of the costs of goods manufactured is as follows. There are arguments that the details of composition of the costs of goods manufactured should be disclosed because they are useful for accounting information users to figure out firms' management performance to predict firms' future cash flows. While, there are other arguments that the details of composition of the costs of goods manufactured should not be disclosed because they fall under firms' trade secrets. The standards accepted the latter logic and did not include the details of composition of the costs of goods manufactured such as raw materials, labor costs, and manufacturing overheads in the mandatory disclosure items ${ }^{4}$. That is, the amended financial reporting standards accepted the latter (based on the proprietary cost theory), rather than the former (based of the

\footnotetext{
${ }^{3}$ Compulsory disclosure refers to the disclosure forced by the law that stipulate items that must be disclosed and the form of disclosure such as periodic disclosure and mandatory non-scheduled disclosure. Voluntary disclosure refers to the free disclosure made by firms pursuant to the managers' arbitrary judgment through press media such as economic newspapers, investment relations (IR), and electronic disclosure systems (Kim et al., 2016).

${ }^{4}$ Korea Accounting Standards board of Korea Accounting Institute 2006. 2. 6.
} 
perspective of valuation). Accordingly, the schedule of manufacturing cost is not a mandatory disclosure item any further, but is a voluntary disclosure item.

Although it was not mandatory disclosure, Kim et al. (2016) identified that there are firms that voluntarily disclose the schedule of manufacturing cost and analyzed what incentives such firms make to voluntarily disclose of the schedule of manufacturing cost. They found that firms with lower ages and higher debt ratios, sales cost ratios, and management performance more frequently make voluntary disclosures of manufacturing cost information. By contrast, the firms with higher productivity and industrial competitiveness, less frequently make voluntary disclosures of manufacturing cost information, thereby supporting the proprietary cost theory. In addition, they found that firms with cost stickiness or firms audited by Big 4 audit firms do not disclose manufacturing cost information.

Bae et al. (2013) empirically analyzed whether voluntary disclosure of the schedule of manufacturing cost reduces the costs of borrowed capitals. The analysis period was from 2006 to 2010 and the analyzed firms were KOSPI and KOSDAQ firms listed on the Korea Exchange. They concluded that the firms that voluntarily disclose the schedule of manufacturing cost are low the costs of borrowed capital, as compared to the firms that do not voluntarily it. These results suggest that the voluntary disclosure of the schedule of manufacturing cost removes information asymmetry between firms and capital investors and reduces capital costs.

To summarize the results of previous studies, disclosure information voluntarily provided by firm solves the problem of information asymmetry between firms and investors in general, but there is also a possibility of increasing information asymmetry when the manager provides arbitrary information. If a manager voluntarily provides information as an effort to reduce information asymmetry and if reliable information is provided to analysts, the accuracy of analysts' earnings forecasts will be increased. In such cases, the analysts provide useful information to the capital market through earnings forecasting, thereby reduce information asymmetry between managers and investors (Han and Shin, 2015). By contrast, providing information biased in favor of his/her firm to pursue personal gains from an opportunistic viewpoint will lead to opposite results. That is, when the quality of information provided by a firm is lower and the uncertainty is higher, the reliability of the earnings forecast information provided by analysts cannot but be lower (Song, 2008). Therefore, the effects of voluntary disclosure on analysts' earnings forecasts may be both positive (+) and negative (-). Since voluntary disclosure is positively or negatively correlated with analysts' earnings forecasts depending on cases as such, the effects of voluntary disclosure on analysts' earnings forecasts are an empirical problem. Based on these conflicting views, we propose the following null hypotheses:

H1: Voluntary disclosure of the schedule of manufacturing cost does not affect analysts' earnings forecasts.

H1a: Voluntary disclosure of the schedule of manufacturing cost does not affect the accuracy of analysts' earnings forecasts.

H1b: Voluntary disclosure of the schedule of manufactured does not affect the biases (overestimation or underestimation) in analysts' earnings forecasts.

\section{RESEARCH DESIGN}

\subsection{Empirical Models}

We use the following multivariate model to test the effect of voluntary disclosure of the schedule of manufacturing cost on analysts' earnings forecasts. Specifically, analysts' earnings forecasts are separately analyzed for the accuracy of analysts' earnings forecasts (AFACC) and bias in analysts' earnings forecasts (AFBIAS).

$$
\begin{aligned}
& A F A C C_{i t}=\beta_{0}+\beta_{1} V_{D U M}+\beta_{2} E Q_{i t}+\beta_{3} F O L L O W S_{i t}+\alpha_{4} L E V_{i t}+\beta_{5} R O E_{i t}+\beta_{6} S_{I Z E_{i t}} \\
& +\beta_{7} A G E_{i t}+\beta_{8} G R W_{i t}+\sum Y D+\sum I N D+\varepsilon_{t} \\
& A F B I A S_{i t}=\beta_{0}+\beta_{1} V D U M_{i t}+\beta_{2} E Q_{i t}+\beta_{3} F O L L O W S_{i t}+\alpha_{4} L E V_{i t}+\beta_{5} R O E_{i t}+\beta_{6} S I Z E_{i t} \\
& +\beta_{7} A G E_{i t}+\beta_{8} G R W_{i t}+\sum Y D+\sum I N D+\varepsilon_{t}
\end{aligned}
$$


Consistent with prior studies, we measure accuracy as the unsigned forecast error defined as the absolute value of forecast error: $A F A C C_{i t}=\left|A F_{i t}-A E_{i t}\right| / P_{i t}$, where $A F_{i t}$ is analysts' forecast for firm $i$ for the fiscal year $t$ and $A E_{i t}$ is the actual realized earnings per share for firm $i$ in year $t$ and $P_{i t}$ is market value per share for firm $i$ in year $t$. To ease exposition, we multiply the accuracy variable by -1 so that a higher value suggests a more accurately forecasts. The bias as the signed forecast error defined as $A F B I A S_{i t}=\left(\mathrm{AF}_{\mathrm{it}}-\mathrm{AE}_{\mathrm{it}}\right) / \mathrm{P}_{\mathrm{it}}$, where $\mathrm{AF}_{\mathrm{it}}$ is analysts' forecast for firm $\mathrm{i}$ for the fiscal year $t$ and $\mathrm{AE}_{\mathrm{it}}$ is the actual realized earnings per share for firm $\mathrm{i}$ in year $\mathrm{t}$. If forecast error is positive $(+)$, the earnings forecasts are overestimated, and if it is negative (-), the earnings forecasts are underestimated. $V_{D U M}$ is a voluntary disclosure dummy, which is 1 for the firms that made voluntary disclosure and 0 otherwise. As a variable of interest of Hypotheses $1_{\mathrm{a}}$ and $1_{\mathrm{b}}$, the sign of $\beta_{1}$ does not predict the direction according to previous studies. If the voluntary disclosure has positive functions, the value of the accuracy of earnings forecasts should have positive $(+)$ direction, and if the voluntary disclosure has negative functions, direction should be negative (-). The value of bias in earnings forecasts should have negative (-) direction in the case of underestimation and positive (+) direction in the case of overestimation.

Based on the results of previous studies, earnings quality (EQ), the number of analysts (FOLLOWS), and the number of years from the date of initial listing to the end of the previous period (AGE) are included as control variables. For earnings quality (EQ), we use the most popular method in the literature based on the modified Jones Model (1995). We also include financial leverage (LEV), return on equity (ROE), firm size (SIZE), asset growth (GRW). Finally, we include industry (IND) and year (YD) fixed effect. Appendix describes how all of these variables are constructed.

\subsection{Measurement of Variables}

\subsubsection{Analysts' Earnings Forecasts}

A significant body of research on analysts' earnings forecasts has investigated their accuracy and bias (Brown, 1993; Das et al., 1997). Consistent with prior studies, we measure accuracy as the unsigned forecast error defined as the absolute value of forecast error: $A F A C C_{i t}=\left|A F_{i t}-A_{i t}\right| / P_{i t}$ where, $A F_{i t}$ is analysts' forecast for firm $i$ for the fiscal year $t, \mathrm{AE}_{\mathrm{it}}$ is the actual realized earnings per share for firm $\mathrm{i}$ in year $\mathrm{t}$, and $\mathrm{P}_{\mathrm{it}}$ is market value per share for firm $\mathrm{i}$ in year t. To ease exposition, we multiply the accuracy variable by -1 so that a higher value suggests a more accurately forecasts. The bias as the signed forecast error defined as $A F B I A S_{i t}=\left(A_{i t}-A E_{i t}\right) / P_{i t}$, where $A F_{i t}$ is analysts' forecast for firm $i$ for the fiscal year $t$ and $\mathrm{AE}_{\mathrm{it}}$ is the actual realized earnings per share for firm $\mathrm{i}$ in year $\mathrm{t}$. If forecast error is positive $(+)$, the earnings forecasts are overestimated, and if it is negative (-), the earnings forecasts are underestimated.

\subsubsection{The Voluntary Disclosure of The Schedule of Manufacturing Cost}

In this study, whether or not a firm make voluntary disclosure is measured as follows. The five items (raw materials, labor costs, manufacturing overheads, total manufacturing cost for the year, costs of goods manufactured during the year) that are considered to be the most important cost items among the items of the schedule of manufacturing cost are selected. Then, if each of the items are disclosed, it becomes a dummy variable having a value of 1 , and a value of 0 otherwise. Thereafter, firms are regarded to have voluntarily disclosed the schedule of manufacturing cost when the sum of the five dummy variables was 5 (when all five items are disclosed). Thus, if five manufacturing cost items are disclosed, it becomes a dummy variable (VDUM) having a value of 1, and a value of 0 otherwise (Kim et al., 2016).

\subsubsection{The Quality of Earnings}

There is no universally accepted measure of the quality of earnings. We employ a modified version of the Jones Model (Dechow et al., 1995) that have been used in prior research. The modification is designed to eliminate the conjectured tendency of Jones Model to measure discretionary accruals with error when discretion is exercised over revenues. Specifically, we estimate the following model by year and for each industry that has at least 10 observations:

$$
T A C_{i t}=\alpha_{0}\left(1 / A_{i t-1}\right)+\alpha_{1}\left(\Delta R E V_{i t}-\Delta A R_{i t}\right)+\alpha_{2} P P E_{i t}+\varepsilon_{i t}
$$


where, $\mathrm{TAC}_{\mathrm{it}}$ is total accruals, measured as the change in non-cash current assets minus the change in current noninterest-bearing liabilities, minus depreciation and amortization expense for firm $\mathrm{i}$ at year $\mathrm{t}$, scaled by lagged total assets $\left(A_{i t-1}\right) ; \triangle R E V_{i t}$ is the annual change in revenues scaled by lagged total assets; $\triangle A R_{i t}$ is the annual change in accounts receivable; $\mathrm{PPE}_{\mathrm{it}}$ is property, plant, and equipment for firm $\mathrm{i}$ at year $\mathrm{t}$, scaled by lagged total assets. The residuals from the regression model are discretionary accruals. In this study, we use the absolute values of discretionary accruals as a proxy for the quality of earnings. We multiply the absolute values of discretionary accruals by $-1(E Q)$. Thus, higher values of EQ represent higher the quality of earnings.

\subsection{Sample Selection}

In this study, our sample consist of firms listed on the Korea Composite Stock Price Index (KOSPI) during the period 2004-2014. We obtain financial data from FN Data-Guide and KIS-VALUE database, which provides the financial statements of all listed firms. For comparability, we exclude firms with non-December fiscal year-ends and all firms in which total liabilities are larger than the total assets. Table 1 shows the sample selection criteria and the number of excluded firms to arrive at our final sample. This screening procedure yielded a total of 1,998 firm-year observations. The financial data of the samples for analysis are winsorized at extreme value $1 \%$ before being used ${ }^{5}$.

Table 1. Sample Selection

\begin{tabular}{l|c}
\hline \multicolumn{1}{|c}{ Sample Selection Criteria } & N \\
\hline Firm-year observations listed on the KOSPI as of the end of December during the period 2002-2011 & 7,632 \\
\hline (Less) Firm-year observations for which financial data are not available & $(435)$ \\
\hline (Less) Firm-year observations without the analysts' forecast information & $(4,512)$ \\
\hline (Less) Firm-year observations with non-December fiscal year-ends and banking & $(687)$ \\
\hline Total number of firm-year observations in the final sample & 1,998 \\
\hline
\end{tabular}

\section{EMPRICAL RESULTS}

\subsection{Descriptive Statistics and Correlation Analysis}

Table 2 shows the descriptive statistics of major variables. The mean (median) of the accuracy of analysts' earnings forecasts (AFACC) is $-0.072(-0.028)$, and the mean (median) of analysts' bias in earnings forecasts (AFBIAS) is 0.047 (0.014). The firms that make voluntary disclosure (VDUM) show the mean of 0.316 , indicating that is about $30 \%$ of the samples voluntarily disclosed the schedule of manufacturing cost. The quality of earnings (EQ) show the mean of -0.054 and the number of analysts (FOLLOWS) show the mean of 6.33 . Financial leverage (LEV) show the mean of 0.491 and the median of 0.506 and return on equity (ROE) show the mean of $2.96 \%$ and the median of $8.64 \%$. The mean (median) of Firm sizes (SIZE) is 27.731 (27.473). The number of years after listing (AGE) show the mean of 18.37 and the median of 17 and asset growth (GRW) show the mean of $26.7 \%$ and the median of $9.9 \%$. Since financial leverage (LEV) and firm sizes (SIZE) show the means that are very close to their medians, their distributions can be assumed to be close to normal distribution. Return on equity (ROE) and asset growth (GRW) can be seen that the distribution is uneven, because large differences between their means and medians are observed.

\footnotetext{
${ }^{5}$ The results of analysis after removing extreme value $1 \%$ of the data showed similar values to those of the winsorized empirical results. 
Table 2. Descriptive Statistics

\begin{tabular}{l|c|c|c|c|c|c|c}
\hline \multicolumn{1}{c|}{ Variable } & Mean & Std. & Min & Q1 & Median & Q3 & Max \\
\hline AFACC & -0.072 & 0.147 & -1.384 & -0.073 & -0.028 & -0.010 & 0.000 \\
\hline AFBIAS & 0.047 & 0.154 & -0.260 & -0.006 & 0.014 & 0.057 & 1.384 \\
\hline VDUM & 0.316 & 0.465 & 0.000 & 0.000 & 0.000 & 1.000 & 1.000 \\
\hline$E Q$ & -0.054 & 0.056 & -0.305 & -0.071 & -0.037 & -0.016 & 0.000 \\
\hline FOLLOWS & 6.326 & 6.247 & 0.000 & 1.000 & 4.000 & 10.000 & 30.000 \\
\hline$L E V$ & 0.491 & 0.187 & 0.118 & 0.340 & 0.506 & 0.633 & 0.903 \\
\hline$R O E$ & 2.958 & 21.770 & -46.960 & 1.660 & 8.640 & 15.080 & 44.520 \\
\hline SIZE & 27.731 & 1.567 & 24.852 & 26.558 & 24.473 & 28.784 & 31.873 \\
\hline$A G E$ & 18.367 & 12.448 & 0.000 & 7.000 & 17.000 & 29.000 & 57.000 \\
\hline$G R W$ & 0.267 & 1.380 & -0.982 & 0.007 & 0.099 & 0.225 & 15.386 \\
\hline
\end{tabular}

Note: This table presents the descriptive statistics for the variables used in the sample (1,998 firm-year observations) including the listed firms on the Korea Composite Stock Price Index (KOSPI) over the period 2004 to 2014. See the Appendix for variable definitions.

Table 3 shows the results of Pearson correlations of major variables. The accuracy of analysts' earnings forecasts (AFACC) are significantly positively correlated with earnings quality (EQ), the number of analysts (FOLLOWS), and return on equity (ROE). This means that analysts' earnings forecasts are more accurate for the firms with better earnings quality, larger numbers of analysts, and larger return on equity. By contrast, AFACC is significantly negatively correlated with the voluntary disclosure dummy (VDUM), financial leverage (LEV), and the number of years after listing (AGE). This means that analysts' earnings forecasts are less accurate for the firms that make voluntary disclosure, have higher debt ratios, and have larger numbers of years after listing.

Analysts' bias in earnings forecasts (AFBIAS) are significantly negatively correlated with earnings quality (EQ), the number of analysts (FOLLOWS), and return on equity (ROE). This means that actual earnings per share are larger than analysts' earnings forecasts, that is, analysts underestimate earnings per share in the case of the firms with better earnings quality, larger numbers of analysts, and larger returns on equity. As correlation results do not control for differences in firm, industry characteristics, we now turn to multivariate tests.

Table 3. Correlations among the Variables

\begin{tabular}{|c|c|c|c|c|c|c|c|c|c|}
\hline & AFBIAS & $V D U M$ & $E Q$ & FOLLOWS & $L E V$ & ROE $t$ & SIZE & $A G E$ & $G R W$ \\
\hline$A F A C C$ & -0.864 & -0.039 & 0.081 & 0.117 & -0.238 & 0.243 & 0.007 & -0.065 & 0.009 \\
\hline$A F B I A S$ & & 0.028 & -0.066 & -0.095 & 0.207 & -0.279 & -0.023 & 0.031 & -0.015 \\
\hline$V D U M$ & & & 0.022 & -0.142 & 0.136 & 0.083 & -0.134 & 0.025 & -0.039 \\
\hline$E Q$ & & & & 0.070 & -0.027 & -0.069 & 0.145 & 0.115 & 0.020 \\
\hline FOLLOWS & & & & & 0.054 & 0.011 & 0.536 & 0.020 & 0.004 \\
\hline$L E V$ & & & & & & -0.078 & 0.428 & 0.130 & 0.060 \\
\hline$R O E$ & & & & & & & -0.051 & -0.100 & -0.023 \\
\hline SIZE & & & & & & & & 0.259 & 0.090 \\
\hline$A G E$ & & & & & & & & & -0.107 \\
\hline
\end{tabular}

Note: This table reports Pearson correlations for variables. Coefficients shown in bold are significant at $\mathrm{p}<0.05$ (two-tailed test). See the Appendix for all variable definitions.

\subsection{Multivariate Results}

\subsubsection{Analysis of Voluntary Disclosure and the Accuracy of Analysts' Earnings Forecast}

Table 4 shows the results of regression analysis of Equation (1) for the effects of voluntary disclosure on the accuracy of analysts' earnings forecasts. The $\mathrm{F}$ value in the analysis results is statistically significant, which indicates that the research model is appropriate ${ }^{6}$. In Table 4 , the regression coefficient $\left(\beta_{1}\right)$ of VDUM that shows the effect of voluntary disclosure on the accuracy of analysts' earnings forecast have significant positive $(+)$ values, although there are

\footnotetext{
${ }^{6}$ The variance inflation factor (VIF) of the independent variables used in the regression of this study is less than 2.5 , which is less than 10 , indicating that the problem of multicollinearity is not significant.
} 
differences among analysis periods. The analysis period of 2005-2014 is the most significant ${ }^{7}$. This means that the accuracy of analysts' earnings forecasts is higher in the case of the firms that make voluntary disclosure than in the case of other firms. These results support Hypothesis $1_{\mathrm{a}}$ and are consistent with previous studies that voluntary disclosure mitigates information asymmetry between firms and investors, which improves the accuracy of analysts' earnings forecasts.

For control variables, the quality of earnings (EQ), the number of analysts (FOLLOWS), return on equity (ROE), and firm sizes (SIZE) show a significant positive $(+)$ relationship with the accuracy of analysts' earnings forecasts (AFACC), while financial leverage (LEV) show a significant negative (-) relationship with the accuracy of analysts' earnings forecasts (AFACC).

Table 4. The Effects of Voluntary Disclosure on the Accuracy of Analysts' Earnings Forecast

\begin{tabular}{|c|c|c|c|c|c|c|}
\hline \multicolumn{7}{|c|}{$\begin{array}{l}\text { AFACC }_{i t}=\beta_{0}+\beta_{1} V D U M_{i t}+\beta_{2} E Q_{i t}+\beta_{3} F O L L O W S_{i t}+\alpha_{4} L E V_{i t}+\beta_{5} R O E_{i t}+\beta_{6} S_{I Z E_{i t}}+\beta_{7} A G E_{i t} \\
+\beta_{8} G R W_{i t}+\sum Y D+\sum I N D+\varepsilon_{t}\end{array}$} \\
\hline \multirow{2}{*}{ Variable } & \multicolumn{2}{|c|}{$2004-2014(N=1,998)$} & \multicolumn{2}{|c|}{$2005-2014(N=1,819)$} & \multicolumn{2}{|c|}{$2007-2014(N=1,388)$} \\
\hline & Coefficient & t-value & Coefficient & t-value & Coefficient & t-value \\
\hline Intercept & $-0.184^{* * *}$ & -3.34 & $-0.239^{* * *}$ & -3.07 & $-.217^{* * *}$ & -3.22 \\
\hline$V D U M$ & $0.013^{*}$ & 1.79 & $0.021^{* * *}$ & 2.76 & $0.020^{*}$ & 1.87 \\
\hline$E Q$ & $0.147^{* *}$ & 2.53 & $0.142^{* *}$ & 2.37 & $0.180^{* *}$ & 2.3 \\
\hline FOLLOWS & $0.002^{* * *}$ & 3.16 & $0.002^{* * *}$ & 3.16 & $0.002^{* * *}$ & 2.65 \\
\hline$L E V$ & $-0.192^{* * *}$ & -9.5 & $-0.188^{* * *}$ & -8.94 & $-0.204^{* * *}$ & -7.83 \\
\hline$R O E$ & $0.001^{* * *}$ & 9.29 & $0.001^{* * *}$ & 8.73 & $0.001^{* * *}$ & 6.77 \\
\hline SIZE & $0.010^{* * *}$ & 3.53 & $0.010^{* * *}$ & 3.18 & $0.009^{* *}$ & 2.46 \\
\hline$A G E$ & $-0.001^{*}$ & -1.91 & -0.001 & -1.57 & -0.001 & -1.32 \\
\hline$G R W$ & 0.002 & 0.66 & 0.001 & 0.59 & 0.001 & 0.37 \\
\hline Year and Industry Dummy & \multicolumn{2}{|c|}{ Included } & \multicolumn{2}{|c|}{ Included } & \multicolumn{2}{|c|}{ Included } \\
\hline$F$-value & \multicolumn{2}{|c|}{$12.54^{* * *}$} & \multicolumn{2}{|c|}{$13.71^{* * *}$} & \multicolumn{2}{|c|}{$10.09^{* * *}$} \\
\hline $\operatorname{Adj.} R^{2}$ & \multicolumn{2}{|c|}{$14.49 \%$} & \multicolumn{2}{|c|}{$14.29 \%$} & \multicolumn{2}{|c|}{$13.46 \%$} \\
\hline
\end{tabular}

\subsubsection{Analysis of Voluntary Disclosure and the Analysts' Bias in Earnings Forecast}

Table 5 shows the results of regression analysis of Equation (1) for the effects of voluntary disclosure on analysts' bias in earnings forecasts. The $\mathrm{F}$ value in the analysis results is statistically significant, which indicates that the research model is appropriate. In Table 5, the regression coefficient $(\beta 1)$ of VDUM that shows the effect of voluntary disclosure on analysts' bias in earnings forecasts have significant negative values, although there are differences among analysis periods. The analysis period of 2005-2014 is the most significant This means that analysts underestimate earnings per share, that is, actual earnings per share are larger than analysts' earnings per share forecasts in the case of the firms that make voluntary disclosure in the case of other firms. These results indicate that analysts underestimate earnings per share in the case of those firms that make voluntary disclosure, which supports Hypothesis $1_{\mathrm{b}}$.

For control variables, the quality of earnings (EQ), number of analysts (FOLLOWS), return on equity (ROE), and firm sizes (SIZE) shows significant negative (-) relationship with analysts' bias in earnings forecasts (AFBIAS), while financial leverage (LEV) shows significant positive $(+)$ relationship with analysts' bias in earnings forecasts (AFBIAS).

\footnotetext{
${ }^{7}$ We follow the base year and definition of voluntary disclosure as defined by Kim et al. (2016). In previous studies, three base years are defined based on the customs of notifying the time of application of changes in disclosure environments and considering the time for firms to recognize the abolition of the provision for mandatory disclosure. The first base year is 2004 when the Financial Services Commission decided to apply the amended financial reporting standards, and the second base year is 2005 when the Korea Accounting Standards Board decided to apply the full text of the amended enterprise accounting standards. Finally, since firms may continue disclosure without recognizing the abolition of the existing provision for mandatory disclosure, 2007 is set as the third base year considering the period necessary for firms to recognize the change in the provision (Kim et al., 2016). Therefore, this study presents all of the empirical results with the analysis period of 2004-2014, 2005-2014, and 2007-
} 2014 according to the above three base years. 
Table 5. The Effects of Voluntary Disclosure on the Analysts' Bias in Earnings Forecast

\begin{tabular}{|c|c|c|c|c|c|c|}
\hline \multicolumn{7}{|c|}{$\begin{array}{l}A F B I A S_{i t}=\beta_{0}+\beta_{1} V D U M_{i t}+\beta_{2} E Q_{i t}+\beta_{3} F_{O L L O W S_{i t}}+\alpha_{4} L E V_{i t}+\beta_{5} R O E_{i t}+\beta_{6} S_{I Z E_{i t}}+\beta_{7} A G E_{i t}+\beta_{8} G R W_{i t}+ \\
\sum Y D+\sum I N D+\varepsilon_{t}\end{array}$} \\
\hline \multirow{2}{*}{ Variable } & \multicolumn{2}{|c|}{$2004-2014(\mathrm{~N}=1,998)$} & \multicolumn{2}{|c|}{$2005-2014(N=1,819)$} & \multicolumn{2}{|c|}{$2007-2014(N=1,388)$} \\
\hline & Coefficient & t-value & Coefficient & t-value & Coefficient & t-value \\
\hline Intercept & $0.278^{* * *}$ & 3.55 & $0.243^{* * *}$ & 2.97 & $0.208^{* * *}$ & 3.04 \\
\hline$V D U M$ & $-0.016^{* *}$ & -2.01 & $-0.018^{* *}$ & -2.23 & $-0.019^{*}$ & -1.76 \\
\hline$E Q$ & $-0.113^{*}$ & -1.86 & -0.094 & -1.5 & $-0.150^{*}$ & -1.84 \\
\hline FOLLOWS & $-0.002^{* *}$ & -2.38 & $-0.002^{* *}$ & -2.48 & $-0.002^{* *}$ & -2.26 \\
\hline$L E V$ & $0.190^{* * *}$ & 8.97 & $0.189^{* * *}$ & 8.56 & $0.205^{* * *}$ & 7.57 \\
\hline$R O E$ & $-0.002^{* * *}$ & -10.98 & $-0.001^{* * *}$ & -9.63 & $-0.001^{* * *}$ & -7.3 \\
\hline SIZE & $-0.011^{* * *}$ & -3.68 & $-0.010^{* * *}$ & -3.12 & $-0.009^{* *}$ & -2.32 \\
\hline$A G E$ & 0.001 & 0.67 & 0.001 & 0.46 & 0.001 & 0.18 \\
\hline$G R W$ & -0.001 & -0.38 & -0.001 & -0.59 & -0.001 & -0.37 \\
\hline Year and Industry Dummy & \multicolumn{2}{|c|}{ Included } & \multicolumn{2}{|c|}{ Included } & \multicolumn{2}{|c|}{ Included } \\
\hline F-value & \multicolumn{2}{|c|}{$14.62^{* * *}$} & \multicolumn{2}{|c|}{$12.58^{* * *}$} & \multicolumn{2}{|c|}{$9.53^{* * *}$} \\
\hline Adj. $R^{2}$ & \multicolumn{2}{|c|}{$13.95 \%$} & \multicolumn{2}{|c|}{$13.18 \%$} & \multicolumn{2}{|c|}{$12.73 \%$} \\
\hline
\end{tabular}

\subsection{Additional Analysis}

\subsubsection{Analysis According to Determinants of Disclosure}

Kim et al. (2016) select firm age, debt ratios, returns on equity, and industrial concentration as determinants for voluntary disclosure of the schedule of manufacturing cost and report empirical results. Thus, we further analyze how the analysts' earnings forecast differ according to debt ratio and firm age among the determinants of voluntary disclose (debt ratios, firm age). Table 6 and Table 7 show the results of regression analysis, which is divided into the above group and the below group based on the median of the debt ratios (LEV) and firm age (AGE), respectively.

Previous studies regarding debt ratios (LEV) report that firms tend to voluntarily provide information on firms' business as a part of the effort to prevent the termination of debt contracts or deterioration of liquidity (Francis et al., 2005; Kim et al., 2016). In Table 6, the results yield a statistical significance in the above group with higher debt ratios. The group with higher debt ratios show a higher accuracy of analysts' forecasts and underestimation. This suggests that the higher debt ratios, the greater incentives to reduce information asymmetry through voluntary disclosure. 
Table 6. Analysis of the debt ratios (LEV) among Determinant of Disclosure

\begin{tabular}{|c|c|c|c|c|}
\hline \multicolumn{5}{|c|}{ Panel A: The Accuracy of Analysts' Earnings Forecast } \\
\hline \multirow{2}{*}{ Variable } & \multicolumn{2}{|c|}{ LEV $>$ Median } & \multicolumn{2}{|c|}{ LEV $>$ Median } \\
\hline & Coefficient & t-value & Coefficient & t-value \\
\hline Intercept & -0.202 & -1.35 & $-0.239^{* * *}$ & -3.24 \\
\hline$V D U M$ & $0.031^{* * *}$ & 2.92 & -0.003 & -0.4 \\
\hline$E Q$ & 0.146 & 1.23 & 0.080 & 1.51 \\
\hline FOLLOWS & $0.003^{* * *}$ & 3.03 & 0.001 & 1.6 \\
\hline$L E V$ & $-0.521^{* * *}$ & -6.05 & $-0.107^{* * *}$ & -4.56 \\
\hline$R O E$ & $0.002^{* * *}$ & 8.35 & $0.001^{* * *}$ & 2.79 \\
\hline SIZE & $0.017^{* * *}$ & 2.96 & $0.009^{* * *}$ & 3.14 \\
\hline$A G E$ & -0.001 & -1.53 & $-0.001^{*}$ & -1.9 \\
\hline$G R W$ & 0.005 & 1.16 & -0.001 & -0.52 \\
\hline Year and Industry Dummy & \multicolumn{2}{|c|}{ Included } & \multicolumn{2}{|c|}{ Included } \\
\hline$F$-value & \multicolumn{2}{|c|}{$21.54^{* * *}$} & \multicolumn{2}{|c|}{$4.8^{* * *}$} \\
\hline $\operatorname{Adj} . R^{2}$ & \multicolumn{2}{|c|}{$9.96 \%$} & \multicolumn{2}{|c|}{$6.89 \%$} \\
\hline
\end{tabular}

Panel B: The Analysts' Bias in Earnings Forecast

\begin{tabular}{|c|c|c|c|c|}
\hline \multirow{2}{*}{ Variable } & \multicolumn{2}{|c|}{ LEV $>$ Median } & \multicolumn{2}{|c|}{ LEV > Median } \\
\hline & Coefficient & t-value & Coefficient & t-value \\
\hline Intercept & 0.248 & 1.57 & $0.245^{* * *}$ & 3.21 \\
\hline$V D U M$ & $-0.035^{* *}$ & -2.27 & 0.001 & 0.13 \\
\hline$E Q$ & -0.173 & -1.38 & 0.008 & 0.15 \\
\hline FOLLOWS & -0.002 & -1.21 & -0.001 & -1.41 \\
\hline$L E V$ & $0.557^{* * *}$ & 6.12 & $0.075^{* * *}$ & 3.09 \\
\hline$R O E$ & $-0.003^{* * *}$ & -8.54 & $-0.001^{* * *}$ & -5.52 \\
\hline SIZE & $-0.021^{* * *}$ & -3.39 & $-0.008^{* * *}$ & -2.86 \\
\hline$A G E$ & 0.001 & 1.27 & 0.000 & -0.48 \\
\hline$G R W$ & -0.005 & -1.08 & 0.003 & 1.09 \\
\hline Year and Industry Dummy & \multicolumn{2}{|c|}{ Included } & \multicolumn{2}{|c|}{ Included } \\
\hline$F$-value & \multicolumn{2}{|c|}{$9.69^{* * *}$} & \multicolumn{2}{|c|}{$4.04^{* * *}$} \\
\hline Adj. $R^{2}$ & \multicolumn{2}{|c|}{$21.03 \%$} & \multicolumn{2}{|c|}{$5.58 \%$} \\
\hline
\end{tabular}

Note: This table presents the analysis of the debt ratios (LEV) among determinant of disclosure. ${ }^{*}, * *, * * *$ indicate significance at the 10 percent, 5 percent, and 1 percent levels respectively, based on two-tailed test. See the Appendix for variable definitions.

Previous studies regarding firm age (AGE) report that the longer firm age, the better information environment and the more likely the analysts are interested (Blinski, 2014; Shin and Oh, 2014). In Table 7, the results yield a statistical significance in the above group with longer firm age. Older firms exhibit a higher accuracy of analysts' forecasts and underestimation. This is consistent with the results of previous studies that the longer firm age, the better information environment of the market. In the case of the below group with shorter firm age, voluntary disclosure shows positive $(+)$ relationship with the accuracy of earnings forecasts and underestimation, although not statistically significant. 
Table 7. Analysis of the firm age (AGE) among Determinant of Disclosure

\begin{tabular}{|c|c|c|c|c|}
\hline \multicolumn{5}{|c|}{ Panel A: The Accuracy of Analysts' Earnings Forecast } \\
\hline \multirow{2}{*}{ Variable } & \multicolumn{2}{|c|}{ LEV $>$ Median } & \multicolumn{2}{|c|}{ LEV > Median } \\
\hline & Coefficient & t-value & Coefficient & t-value \\
\hline Intercept & $-0.303^{* * *}$ & -2.78 & $-0.159^{* * *}$ & -1.69 \\
\hline$V D U M$ & $0.022^{* * *}$ & 2.89 & 0.010 & 1.02 \\
\hline$E Q$ & 0.119 & 1.21 & $0.130^{*}$ & 1.92 \\
\hline FOLLOWS & $0.002^{* * *}$ & 2.70 & $0.002^{* * *}$ & 2.68 \\
\hline LEV & $-0.249^{* * *}$ & -7.62 & $-0.145^{* * *}$ & -5.75 \\
\hline$R O E$ & $0.002^{* * *}$ & 7.53 & $0.001^{* * *}$ & 5.91 \\
\hline SIZE & $0.014^{* * *}$ & 3.01 & 0.006 & 1.55 \\
\hline$A G E$ & 0.001 & 1.18 & $0.001^{*}$ & 1.91 \\
\hline$G R W$ & $0.012^{*}$ & 1.70 & 0.001 & 0.31 \\
\hline Year and Industry Dummy & \multicolumn{2}{|c|}{ Included } & \multicolumn{2}{|c|}{ Included } \\
\hline$F$-value & \multicolumn{2}{|c|}{$9.35^{* * *}$} & \multicolumn{2}{|c|}{$7.14^{* * *}$} \\
\hline $\operatorname{Adj} . R^{2}$ & \multicolumn{2}{|c|}{$16.96 \%$} & \multicolumn{2}{|c|}{$12.46 \%$} \\
\hline
\end{tabular}

Panel B: The Analysts' Bias in Earnings Forecast

\begin{tabular}{|c|c|c|c|c|}
\hline \multirow{2}{*}{ Variable } & \multicolumn{2}{|c|}{ LEV $>$ Median } & \multicolumn{2}{|c|}{ LEV > Median } \\
\hline & Coefficient & t-value & Coefficient & t-value \\
\hline Intercept & $0.305^{* * *}$ & 2.77 & $0.166^{*}$ & 1.65 \\
\hline$V D U M$ & $-0.023^{* *}$ & -2.27 & -0.016 & -1.55 \\
\hline$E Q$ & -0.069 & -0.69 & -0.072 & -1.10 \\
\hline FOLLOWS & $-0.002^{*}$ & -1.87 & $-0.002^{* * *}$ & -2.81 \\
\hline$L E V$ & $0.260^{* * *}$ & 7.77 & $0.134^{* * *}$ & 4.95 \\
\hline$R O E$ & $-0.002^{* * *}$ & -9.74 & $-0.001^{* * *}$ & -6.04 \\
\hline SIZE & $-0.014^{* * *}$ & -2.88 & -0.006 & -1.41 \\
\hline$A G E$ & $-0.001^{*}$ & -1.95 & -0.001 & -1.59 \\
\hline$G R W$ & -0.010 & -1.33 & -0.003 & -0.35 \\
\hline Year and Industry Dummy & \multicolumn{2}{|c|}{ Included } & \multicolumn{2}{|c|}{ Included } \\
\hline$F$-value & \multicolumn{2}{|c|}{$10.81^{* * *}$} & \multicolumn{2}{|c|}{$5.93^{* * *}$} \\
\hline Adj. $R^{2}$ & \multicolumn{2}{|c|}{$19.36 \%$} & \multicolumn{2}{|c|}{$10.26 \%$} \\
\hline
\end{tabular}

Note: This table presents the analysis of the firm age (AGE) among determinant of disclosure. ${ }^{*}, * *, * *$ indicate significance at the 10 percent, 5 percent, and 1 percent levels respectively, based on two-tailed test. See the Appendix for variable definitions.

\section{CONCLUSION}

In this study, the effects of voluntary disclosure of the schedule of manufacturing cost on analysts' earnings forecasts are analyzed using 1,998 firm-year observations in the period of 2004-2014. Voluntary disclosure plays a positive role of enhancing the efficiency of the capital market by reducing the information asymmetry between managers and investors through transmission of more pieces of information, but it may lower the reliability of financial information due to increased arbitrariness of managers (Sohn et al., 2008). We note the difficulties in the accurate measurement of disclosure as a major cause of the mixed results of empirical analyses. We set up and analyze the disclosure of the schedule of manufacturing cost as a proxy for voluntary disclosure.

The results of our study are as follows. First, the relationship between voluntary disclosure of the schedule of manufacturing cost and the accuracy of analysts' earnings forecasts is significant in the positive (+) direction. This means that the accuracy of analysts' earnings forecasts is higher in the case of the firms that voluntarily disclosed the schedule of manufacturing cost, as compared to other firms. Second, the relationship between voluntary disclosure of the schedule of manufacturing cost and analysts' bias in earnings forecasts is significant in the negative (-) direction. This means that analysts underestimate earnings in the case of the firms that voluntarily disclose the schedule of manufacturing cost, as compared to other firms.

Since the schedule of manufacturing cost is still an interesting item and useful information in the capital market, the results of our study provide important implications not only to managers, but also to investors and supervisory 
authority. Limitations of our study include the fact that not all diverse variables that affect voluntary disclosure and analysts' forecasts are considered. In addition, since we analyze the relationship between voluntary disclosure of the schedule of manufacturing cost and analysts' earnings forecasts, there may be a bias in sampling, as the firms with no information on analysts' earnings forecasts may have been fundamentally excluded from our analyses. Finally, we look forward to a study on the effects of voluntary disclosure of the schedule of manufacturing cost on capital markets and firms in accounting research.

\section{AUTHOR BIOGRAPHIES}

Hyunmin Oh, Ph.D. Candidate, Graduate School of Business, Hanyang University, 222 Wangsimni-ro, Seongdong-gu, Seoul 133-791, South Korea. E-mail: gusals@hanyang.ac.kr (First author).

Sambock Park, Ph.D. Candidate, Graduate School of Business, Hanyang University, 222 Wangsimni-ro, Seongdong-gu, Seoul 133-791, South Korea. E-mail: psp96@hanyang.ac.kr.

Heungjoo Jeon, Professor, Department of Business Administration, Dankook University,119 Dandae-ro, Dongnam-gu, Cheonan-si, Chungcheongnam-do, South Korea. E-mail: angel458@hanmail.net_(Corresponding author).

\section{REFERENCES}

Agrawal, A., S. Chadha, \& M. Chen. (2006). Who is afraid of reg FD? The behavior and performance of sell-side analysts following the SEC's fair disclosure rules. Journal of Business, 79(6), 2811-2834.

Bae, B, E. Han, C. Choi, Y. Noh, J. Shin, \& L. Li. (2013). The effect of voluntary disclosure of the schedule of manufacturing cost on cost of debt. Korean Journal of Taxation Research, 37, 25-43.

Bilinski, P. (2014). Do analysts disclose cash flow forecasts with earnings estimates when earnings quality is low? Journal of Business Finance and Accounting, 41(3), 401-434.

Botosan, C. A. (1997). Disclosure level and the cost of equity capital. The Accounting Review, 72(3), 323-349.

Brown, L. (1993). Earnings forecasting research: Its implications for capital markets research. International Journal of Forecasting, 9, 295-320.

Das, S., C. Levine, \& K. Sivaramakrishnan. (1997). Earnings predictability and bias in analysts' forecasts. Working paper.

Dechow, P., R. Sloan, \& A. Sweeney. (1995). Detecting earnings management. The Accounting Review, 70(2), 193-225.

Diamond, D., \& R. Verrecchia. (1991). Disclosure, liquidity, and the cost of capital. The Journal of Finance, 46(4), 13251359.

Francis, J., R. LaFond, P. Olsson, \& K. Schipper. (2005). The market pricing of accruals quality. Journal of Accounting and Economics, 39, 295-327.

Francis, J., D. Nanda, \& P. Olsson. (2008). Voluntary disclosure, earning quality, and cost of capital. Journal of Accounting Research, 46(1), 53-99.

Han, M., \& Y. Shin. (2015). The impact of level of matching revenue-expense and conservation on earning forecast. The Journal of Business Education, 29(4), 173-203.

Healy, P. M., \& K. G. Palepu. (2001). Information asymmetry, corporate disclosure, and the capital markets: A review of the empirical disclosure literature. Journal of Accounting and Economics, 31(1), 405-440.

Heflin, F., K. Subramanyam, \& Y. Zhang. (2003). Regulation FD and the financial information environment: Early evidence. The Accounting Review, 78(1), 1-37.

Irani, A., \& I. Karamanou. (2003). Regulation fair disclosure, analyst following, and analyst forecast dispersion. Accounting Horizons, 17(1), 15-29.

Kim, M., H. Jung, Y. Choi, \& H. Lee. (2016). A study on the determinants of voluntary disclosure of the schedule of manufacturing costs. Korean Accounting Journal, 25(1), 1-33.

Lee, M., and H. Shin. (2010). Voluntary disclosure and cost of capital. Accounting Information Review, 28(4), 1-23.

Na, Y., \& W. Leem. (2014). An empirical analysis on association between fair disclosures and the cost of equity capital. Korean Accounting Review, 39(1), 1-42.

Oh, H., S. Hong, \& H. Jeon. (2016). The effect of book-tax differences on analysts' forecasts. The Journal of Business Education, 30(3), 163-186.

Schipper, K. (1989). Commentary in earnings management. Accounting Horizons, 3(4), 91-102.

Shane, P., N. Soderstrom, \& S. Yoon. (2001). Earnings and price discovery in the post-reg. FD information environment: A preliminary analysis. Working paper, University of Colorado at Boulder. 
Shin, H., \& H. Oh. (2014). Earnings quality and the joint issuance of analyst earnings and cash flow forecasts. Accounting Information Review, 32(3), 113-137.

Sohn, S., B. Kwak, \& Y. Kim. (2008). The effect of voluntary disclosures on analysts' earnings forecasts. Accounting Information Review, 26(2), 1-26.

Song, M. (2008). How do quarterly earnings announcements affect analyst forecasts? Korean Management Review, 37(6), 1425-1460.

Verrecchia, R. E. (1999). Disclosure and the cost of capital: A discussion. Journal of Accounting and Economics, 26(1), 271-283. 


\section{APPENDIX: Variable Definitions}

\section{Dependent Variables}

$\begin{aligned} & A F A C C_{i t}= \begin{array}{l}\left|\mathrm{AF}_{\mathrm{it}}-\mathrm{AE}_{\mathrm{it}}\right| / \mathrm{P}_{\mathrm{it}}, \text { where } \mathrm{AF}_{\mathrm{it}} \text { is analysts' forecast for firm } \mathrm{i} \text { for the fiscal year } \mathrm{t} \text { and } \mathrm{AE}_{\mathrm{it}} \text { is the actual realized } \\ \text { earnings per share for firm } \mathrm{i} \text { in year } \mathrm{t} \text { and } \mathrm{P}_{\mathrm{it}} \text { is market value per share for firm } \mathrm{i} \text { in year } \mathrm{t} ;\end{array} \\ & \text { eFBIAS }_{i t}=\begin{array}{l}\left(\mathrm{AF}_{\mathrm{it}}-\mathrm{AE}_{\mathrm{it}}\right) / \mathrm{P}_{\mathrm{it}}, \text { where } \mathrm{AF}_{\mathrm{it}} \text { is analysts' forecast for firm } \mathrm{i} \text { for the fiscal year } \mathrm{t} \text { and } \mathrm{AE}_{\mathrm{it}} \text { is the actual realized } \\ \text { earnings per share for firm } \mathrm{i} \text { in year } \mathrm{t} \text {; }\end{array}\end{aligned}$

Explanatory Variables

an indicator variable that indicates firms of the voluntary disclosure of the schedule of manufacturing cost,

$V D U M=1$ if the firm that five manufacturing cost items (raw materials, labor costs, manufacturing overheads, total manufacturing cost for the year, costs of goods manufactured during the year) are disclosed, and 0 otherwise;

\begin{tabular}{|c|c|c|}
\hline \multicolumn{2}{|c|}{ Control variables } & \\
\hline$E Q$ & $=$ & the absolute residual of the Dechow et al. (1995) discretionary accrual model, multiplied by -1 ; \\
\hline FOLLOWS & $=$ & the number of analysts who report earnings forecasts for the firm; \\
\hline$L E V$ & $=$ & financial leverage, measured as long-term liabilities divided by lagged total assets; \\
\hline$R O E$ & $=$ & return on equity, measured as net income divided by lagged total equity; \\
\hline SIZE & $=$ & the natural $\log$ of total assets; \\
\hline$A G E$ & $=$ & the number of years from the date of initial listing to the lagged period; \\
\hline$G R W$ & $=$ & asset growth, measured as the natural $\log$ of total assets in year $t$ divided by total assets in $\mathrm{t}-1$; \\
\hline$Y D$ & $=$ & year dummy; \\
\hline$I N D$ & $=$ & industry dummy. \\
\hline
\end{tabular}

